\title{
Radikalisme Islam atas Nama Dakwah Hisbah Front Pembela Islam
}

\author{
Tata Sukayat \\ Fakultas Dakwah dan Komunikasi, UIN Sunan Gunung Djati Bandung \\ Email:t.sukayat77@gmail.com
}

\begin{abstract}
Some violences in the name of Islam such as rally and sweeping to crime places, carried out by muslim vigilante group affiliated with one of radical Islamic organizations namely Islam Defenders Front (FPI) with its wing organization, Islam Defender Troops (Laskar Pembela Islam). The FPI claims that the action is a part of da'wah activity in the form of hisbah. The aim of this paper is to reveal the meaning of da'wah hisbah, the roots of radical da'wah in Indonesia and the conformity of FPI's radical action with the concept of hisbah in term of Islam. The research approach used qualitative with case study method. Data were obtained through observation, in-depth interview and documentation study. The results show that the radical da'wah in Indonesia according to FPI's opinion has begun since the early days of Islam coming in Indonesia and the claims that FPI's da'wah activity under the term of hisbah actually differ from the original meaning of hisbah in Islam. This research impact on the understanding of hisbah meaning referred to Islam that muslim can not claim perform da'wah of hisbah when they commit violence in enforcing the law.
\end{abstract}

Keywords: radicalism; da'wah; hisbah; Islam Defender Front.

\begin{abstract}
ABSTRAK
Tindak kekerasan mengatasnamakan Islam seperti demonstrasi dan aksi sweeping tempattempat maksiat, dilakukan oleh kelompok muslim yang berafiliasi pada organisasi Islam radikal salah satunya Front Pembela Islam (FPI) dengan sayap organisasi Laskar Pembela Islam. FPI mengklaim bahwa aksi mereka merupakan kegiatan dakwah dalam bentuk hisbah. Tulisan ini mengungkapkan hakikat dakwah hisbah, akar dakwah radikal di Indonesia dan kesesuaian aksi radikal FPI dengan konsep dan norma hisbah dalam Islam. Pendekatan penelitian menggunakan kualitatif dengan metode studi kasus. Data diperoleh melalui pengamatan, observasi, wawancara mendalam dan studi dokumentasi. Hasil penelitian menunjukkan bahwa akar dakwah radikal di Indonesia menurut FPI sudah terjadi sejak masa awal kedatangan Islam di Indonesia dan klaim FPI bahwa aktivitas dakwah mereka sebagai bentuk hisbah tampaknya bukan makna hisbah dalam arti yang utuh seperti istilah dalam Islam. Penelitian ini berdampak pada pelurusan pemahaman tentang arti hisbah sebagaimana dimaksud ajaran Islam sehingga umat Islam tidak mengklaim hisbah ketika berdakwah menegakkan hukum dengan kekerasan.
\end{abstract}

Kata kunci : radikalisme; dakwah; hisbah; Front Pembela Islam.

\section{PENDAHULUAN}

Dalam konteks sejarah Islam di Indonesia polarisasi Islam terjadi sangat besar. Sejak era pra-kemerdekaan, Islam telah menunjukkan beragam wajah yang diwakili oleh kemunculan beberapa organisasi keagamaan. Para pengamat 
keagamaan Islam mengidentifikasi wajah Islam tersebut dengan berbagai nama atau label, seperti Islam santri dan abangan, Islam tradisonalis, Islam modernis, Islam scripturalist (penganut harfiyah pada kitab suci), Islam puritan, Islam subtantif, Islam militant, Islam nasionalis, Islam literal dan sebagainya (Rahmat, 2005: 40). Banyaknya penyebutan Islam tersebut, setidaknya menunjukkan bahwa umat Islam di Indonesia memiliki beragam pemahaman dan penghayatan.

Islam yang beraneka warna tersebut saat ini semakin menampakkan identitas dan ghirahnya. Namun, ada beberapa kelompok tertentu yang dalam praktek keagamaannya, menekankan ketaatan yang penuh kepada apa yang dipraktekkan nabi dan generasi sahabat. Mereka berupaya penuh untuk mengikuti cara hidup Nabi hingga hal-hal yang sekecil-kecilnya. Anjuran untuk meningkatkan keimanan dan ketakwaan kepada Allah dan rasul-Nya berbanding lurus dengan anjuran untuk meninggalkan apa yang mereka anggap "TBC" (tahayul, bid'ah dan khurafat).

Gerakan keislaman ini melihat bahwa dalam kehidupan di masyarakat telah terjadi jurang yang begitu dalam antara harapan seperti yang dikonsepsikan agama dengan kenyataan yang ada di hadapan mereka. Sementara itu, upaya untuk merealisasikan yang diidealkan agama tersebut tidak bisa tercapai tanpa memakai kekuatan, karena elemen pendukung baik kultural maupun struktural dianggap tidak kondusif bagi direalisasikannya harapan tersebut. Dari sinilah muncul gagasan radikalisme agama.

Radikalisme secara popular menunjukkan kepada ekstremisme pemikiran dalam aneka ragam bentuk atau usaha untuk mengubah situasi sosial politik secara drastis dan ekstrem (Shihab, 1999: 282). Gerakan radikalisme ini ditunjukkan dengan adanya segmen masyarakat muslim tertentu yang menekankan konservatisme keagamaan dan keinginan untuk menunjukkan identitas Islamnya dengan cara ekstrem atau tindakan radikal (Burhani, 2001: 24).

Radikalisme keagamaan sebenarnya fenomena yang bisa muncul dalam agama apa saja. Radikalisme sangat berkaitan dengan fundamentalisme, yang ditandai oleh kembalinya masyarakat kepada dasar-dasar agama. Fundamentalisme akan diiringi oleh radikalisme dan kekerasan ketika kebebasan untuk kembali kepada agama dihalangi oleh situasi sosial politik yang mengelilingi masyarakat. Fenomena ini dapat menimbulkan konflik terbuka bahkan kekerasan antara dua kelompok yang berhadapan (Turmudzi, 2004: 5).

Secara umum, pemikiran Islam radikal memiliki pola dan kerangka, yaitu a) Islam seharusnya menjadi dasar negara; b) syariah harus diterima sebagai dasar konstitusi resmi negara; c) kedaulatan politik ada di tangan Tuhan; d) gagasan tentang sebuah negara-bangsa bertentangan dengan konsep umat dalam perspektif Islam yang tidak mengenal batasan politik atau regional (kedaerahan); dan e) prinsip syûra (musyawarah) berbeda dengan ide dan prinsip demokrasi (Zada, 2002: 1). 
Fenomena radikalisme agama di Indonesia tidak dapat dipisahkan dari arus modernisasi dan pembangunan negara selama tiga puluh tahun terakhir. Sementara kolonisasi internal negara dan penetrasi rasionalitas ekonomi dan administrasi ke dalam kehidupan sehari-hari, dalam konteks modernisasi dan pembangunan terus berlanjut. Di sisi lain, negara tidak menyediakan cukup ruang untuk semua segmen masyarakat untuk mengekspresikan diri dan kepentingan mereka. Ungkapan Islam politik misalnya, cenderung terpinggirkan dan terhambat karena dianggap mengganggu proses modernisasi dan model pembangunan yang diterapkan. Akibatnya, terdapat kekecewaan dan rasa tidak berdaya yang dialami oleh berbagai lapisan masyarakat. Hal itu dipercepat dengan meningkatnya proses globalisasi, karena intensifikasi pola hubungan sosial di seluruh dunia telah menghilangkan batasan geografis, sosial, dan politik yang mana ketergantungan pada tatanan global yang lintas budaya tidak dapat dihindari. Proses ini dipastikan menyebabkan tidak sedikir orang yang merasa kehilangan kendali atas kehidupan mereka.

Ketika rasa kecewa dan tidak berdaya meningkat karena tersumbatnya ruang partisipasi publik di bawah hegemoni negara, perlawanan untuk merebut kembali ruang partisipasi tidak dapat dielakkan. Dengan mencoba merebut ruang partisipasi, rasionalitas komunikatif bisa dibawa kembali ke ruang publik. Sementara itu, dalam konstelasi global, ketika negara-negara modern tidak dapat mengintegrasikan semua kekuatan masyarakat melalui kemakmuran ekonomi dan pemuka agama dalam penghargaan resmi kekuasaan agamanya, perlawanan seringkali mengambil bentuk panggilan untuk kembali ke identitas dasar, di mana massa yang merasa dikucilkan dan bagian masyarakat lainnya yang tidak puas dapat merekonstruksi makna dan memberikan pemahaman baru pada kehidupan sosial sebagai alternatif dari realitas yang ada.

Secara umum, kemunculan gerakan Islam radikal sendiri disebabkan oleh dua faktor: Pertama, Internal (faktor dari dalam umat Islam sendiri). Faktor ini dilandasi oleh kondisi umat Islam sendiri yang telah menyimpang dari normanorma agama. Kehidupan sekuler yang mulai merasuk dalam kehidupan umat Islam dengan segala dampaknya mendorong mereka untuk melakukan gerakangerakan kembali kepada dasar (fundamen) Islam. Fundamentalisme Islam berupaya memformulasikan legalitas Islam, merealisasikanya, serta membangun sistem yang islami, kemudian mempertahankannya sedemikian rupa tanpa mengacu pada keunggulan sistem lain yang sudah eksis (Ghafur, 2015: 25).

Dalam perkembangan selanjutnya, fundamentalisme menjadi ciri kelompok agama yang konservatif dan menolak adanya perubahan bahwa gerakannya cenderung bersifat regresif: memurnikan ajaran agama dengan kembali ke nilai yang asli (Asfar, 2003: 25). Sikap ini ditopang oleh pemahaman agama yang totalistik dan formalistik, bersifat kaku dalam memahami teks-teks agama, merujuk secara literal perilaku Nabi di Mekah dan Madinah, sehingga identitas keagamaanya sangat literalistik, kaku dan cenderung menolak 
perubahan sosial.

Kedua, Faktor eksternal (dari luar umat Islam ), yaitu sikap yang dilakukan oleh rezim penguasa maupun hegemoni barat, diantaranya: 1) sikap represif rezim penguasa terhadap kelompok-kelompok Islam, 2) krisis kepemimpinan yang terjadi pasca Orde Baru yang ditunjukkan dengan lemahnya penegakkan hukum, seperti di Ambon, dan 3) praktik kemaksiatan yang terjadi di masyarakat mendorong gerakan Islam yang menyatakan bahwa syari at Islam menjadi solusi terbaik terhadap kondisi tersebut (Zada, 2002: 85-96).

Istilah radikalisme Islam menurut Thalib (2003: 107) menunjuk pada munculnya berbagai gerakan Islam yang menggunakan berbagai bentuk kekerasan dalam rangka perjuangan untuk mendirikan 'Negara Islam'. Sedangkan menurut Rahmat (2005: 153) radikalisme Islam adalah suatu gerakan yang memiliki ciri radikal dengan indikator adanya karakter keras dan tegas, cenderung tanpa kompromi dalam mencapai agenda-agenda tertentu yang berkaitan dengan kelompok muslim tertentu, dan memiliki pandangan dunia (world view) Islam tertentu sebagai sebuah agama. Kesan sebagai karakter gerakan yang keras tersebut bisa terlihat dari nama dan terminologi yang mereka gunakan sebagai nama kelompok yang berkonotasi kekerasan dan militeristik, seperti Jundullah (tentara Allah), Laskar Jihad, Hižbullah (partai Allah) atau Front Pembela Islam.

Secara umum, pada konstelasi politik di Indonesia, diyakini bahwa kelompok radikalis atau pendukung gerakan radikal semakin besar tapi gerakan mereka tidak memiliki pola seragam. Ada yang berjuan untuk penerapan syariat Islam tanpa perlu membangun "negara Islam", ada pula yang mencoba memperjuangkan pembentukan "Negara Islam Indonesia" dan beberapa yang ingin memperjuangkan berdirinya "Islam kbiläfah". Pola organisasi juga bervariasi, salah satunya melalui pola radikal dan gaya militer seperti yang dipraktikkan oleh Front Pembela Islam (FPI).

Front Pembela Islam (FPI) adalah salah satu organisasi Islam cukup terkenal di Indonesia pasca reformasi. Gerakannya sering diwujudkan dalam tindakan radikal yang telah menimbulkan rasa takut dan bahkan menjadi momok bagi sebagian masyarakat. FPI juga adalah salah satu kelompok Islam fundamentalis. Jargon yang mereka gunakan tidak jauh dari doktrin menegakkan hukum Allah, lebih khusus lagi pengenaan hukum Islam, dan penolakan mereka terhadap Barat. Organisasi ini cepat dikenal secara luas oleh publik sejak beberapa tahun terakhir karena aktivitas utama mereka merazia tempat hiburan yang mereka anggap sebagai sarang kemaksiatan seperti klub malam, diskotik, kafe, kasino, dll. (Jamhari, 2004: 129).

Pendirian Front Pembela Islam (FPI) dipelopori oleh Habib Muhammad Rizieq Shihab, seorang habib, ulama, mubalig, serta aktivis Islam (al-Zastrouw, 2006: 95). Dasar hukum perjuangan FPI dalam menegakkan amar ma'rüf nahi munkar adalah tunduk pada syariat Islam. Sedangkan kepada hukum negara, FPI 
akan tunduk sepanjang tidak berbenturan dengan ajaran agama Islam. FPI sebagai organisasi yang berbasiskan massa memiliki sayap organisasi Laskar Pembela Islam, yaitu kelompok paramiliter dari organisasi tersebut yang kontroversial karena melakukan aksi-aksi "penertiban" (sweeping) terhadap kegiatan-kegiatan yang dianggap maksiat atau bertentangan dengan syariat Islam dan sering berujung pada kekerasan.

Tindakan Front Pembela Islam sering dikritik berbagai pihak karena tindakan main hakim sendiri yang berujung pada perusakan hak milik orang lain. Pernyataan bahwa seharusnya Polri adalah satu-satunya intitusi yang berhak melakukan hal tersebut dijawab dengan pernyataan bahwa Polri tidak memiliki insiatif untuk melakukannya. Habib Rizieq, sebagai Imam Besar Front Pembela Islam, menyatakan bahwa Front Pembela Islam merupakan gerakan lugas dan tanpa kompromi sebagai cermin dari ketegaran prinsip dan sikap. Menurut Shihab (2008) kekerasan yang dilakukan Front Pembela Islam adalah bentuk bisbah (menegakkan amar ma'rüf dan menindak pelaku nabi munkar), dikarenakan kemandulan dalam sistem penegakan hukum di Indonesia. Dalam pandangannya, hisbah telah dilakukan sejak awal mula masuk Islam di Indonesia.

Penelitian tentang radikalisme Islam dan FPI bukanlah hal baru. Beberapa tulisan dan penelitian terkait tema ini telah banyak dilakukan. Penelitian Abdul Mukti Ro’uf (2007) misalnya berkisar pada konsep, pemikiran dan historis gerakan radikalisme ormas-ormas Islam garis keras di Indonesia. Saifuddin (2011) dalam penelitiannya menjelaskan tentang anggapan bahwa kelompok Islam militan diikuti oleh kalangan awam mulai disadari kalangan fundamentalis. Pilihan kelompok mahasiswa sebagai agen baru dianggap mampu merubah pola gerakan mereka. Merebaknya kelompok radikal Islam di kalangan mahasiswa tidak terlepas dari upaya kaderisasi kelompok intelektual kalangan fundamentalis Islam dengan strategi yang dilakukan melalui indokrinasi ideologis yang membuat mahasiswa sulit berpisah dari kelompok ini.

Penelitian lainnya dilakukan oleh Eko Aditiya (2013) yang mengkaji tentang nilai-nilai agama yang dipahami oleh anggota FPI Bandung Raya, motif anggota FPI Bandung Raya dalam memaknai radikalisme dan pengalaman beberapa anggota FPI Bandung Raya selama menjadi anggota FPI. Selanjutnya, hasil penelitian Syamsul Ma'arif (2012) menyatakan bahwa berbagai aksi kekerasan FPI merupakan salah satu bentuk ekspresi terdalam dari sekelompok orang muslim dalam mengartikulasikan ajaran-ajaran agama yang dipeluknya, atau sebagai bentuk sikap "kesalehan" atas sesuatu yang diyakininya, termasuk dalam memandang persoalan yang jelas-jelas dianggap sebagai bentuk kemaksiatan, kesesatan dan penodaan agama. Respons dan reaksi mereka menurut Ma'arif (2012) adalah dalam rangka menegakkan prinsip keimanan yang dianggap "benar".

Hasil penelitian Fahruddin Faiz (2017) melihat fenomena kekerasan agama, sebagaimana ditunjukkan dalam berbagai aksi FPI, adalah fenomena 
kekerasan yang lazim muncul dalam ranah-ranah kehidupan. Hanya saja fenomena ini menjadi luar biasa karena agama dijadikan landasan dari aksi kekerasan. Demikian Saeful Anwar (2015) dalam penelitiannya menyatakan bahwa konsep amr ma'rûf dan Nabi munkar merupakan dua konsep utama dalam gerakan Front Pembela Islam. Apapun yang mereka lakukan seperti kegiatan pengajian atau aksi di jalanan, tidak bisa dilepaskan dari dua konsep tersebut. Kategori perbuatan ma'rûf dan munkar yang FPI definisikan, selain bidang agama, juga mencakup bidang sosial, ekonomi, politik dan budaya.

Penelitian Eric Hiarie (2010) menyatakan bahwa aksi kolektif kelompok radikal bisa dilihat sebagai ekspresi dan performa dari sebuah identitas Islam radikal yang dihasilkan oleh sebuah proses internal mengkonstruksikan 'ke-kitaan' gerakan. Dalam rangka mengenali dirinya sendiri, para aktivis memotret kelompoknya sebagai warga muslim paling orisinal yang memiliki kewajiban mulia mewujudkan penerapan shari'ah dan mendirikan otoritas politik Islam serta melakukan jihad dan dakwah untuk memperjuangkan tujuan tersebut.

Kunawi Basyir (2014), dalam tulisannya menyatakan kajian fundamentalisme Islam di Indonesia lebih urgen bila diberikan labeling pada gerakan-gerakan mereka sebagai merupakan respons terhadap ideologi Islam modernis. Di Indonesia, kelompok fundamentalisme ada dua macam, yaitu fundamentalisme yang radikal, seperti Front Pembela Islam (FPI) dan Laskar Jihad, dan fundamentalisme dengan corak aksi damai, seperti Hizbut Tahrir Indonesia (HTI) dan Majelis Mujahidin Indonesia (MMI).

Selanjutnya penelitian Anzar Abdullah (2016) melihat cikal bakal lahirnya aliran atau kelompok maupun organisasi Islam radikal kontemporer sebagai bersumber dari sejarah Islam itu sendiri yang mulanya dipelopori oleh kelompok Khawarij yang keras kepala, tidak mengenal kompromi dan dialog. Kelompok inilah yang kemudian sekarang bermetamorfosis dalam bentuk Hizbut Tahrir Indonesia (HTI), Majelis Mujahidin Indonesia (MMI), Anshorut Tauhid, juga Front Pembela Islam (FPI).

Berbeda dengan beberapa penelitian terdahulu tersebut, penelitian ini lebih mengedepankan kerangka dakwah, yakni pemahaman FPI tentang dakwah amar ma'rüf nahi munkar kaitannya dengan konsep hisbah yang kerap mereka dengungkan. Konsep dakwah hisbah ini menarik dan menjadi latar belakang dari penelitian ini. Sebab, sebagaimana disinggung di atas, bahwa tindakan yang dilakukan FPI tersebut memunculkan berbagai reaksi yang cukup keras dari berbagai pihak, termasuk dianggap menyimpang berdasarkan konsepsi makro obyektivis. Tulisan ini dipandang sebagai hal baru, karena belum ditemukan tulisan lain yang membahas kaitan antara konsep bisbah sebagaimana dipahami FPI dengan konsep hisbah sebagaiman diatur dalam Islam dan telah dipraktikkan kaum muslimin pada masa awal Islam.

Secara khusus, penelitian ini bertujuan untuk mengetahui hakikat dakwah bisbah dan akar dakwah radikal di Indonesia, juga untuk mengetahui kesesuaian 
tindak dan aksi FPI dalam melakukan berbagai tindakan radikal dalam menegakkan amar ma'rüf nahi munkar dengan konsep dan norma hisbah dalam Islam. Dengan demikian, hasil penelitian diharapkan dapat memberikan manfaat, khususnya dalam memberikan pemahaman yang komprehensif tentang amar ma'rüf nahi munkar dalam kaitannya dengan konsep hisbah.

Penelitian ini menggunakan pendekatan kualitatif, yakni prosedur penelitian yang menggunakan latar alamiah tindakan dan pemikiran FPI, dengan maksud menafsirkan fenomena radikalisme FPI dengan menggunakan berbagai metode (Moleong, 2007: 7). Ditinjau dari objek kajiannya, penelitian ini termasuk dalam kategori penelitian observasi dan kepustakaan (library research), yaitu penelitian yang dilakukan dengan cara mengadakan analisis dan studi terhadap fenomena gerakan FPI dan tulisan-tulisan yang berkaitan dengan pokok permasalahan ini. Sedangkan metode penelitian yang digunakan adalah studi kasus. Metode ini dipandang tepat karena metode studi kasus bisa mengkaji secara rinci suatu peristiwa tertentu (Idrus, 2007: 77) yaitu dakwah hisbah FPI.

\section{HASIL DAN PEMBAHASAN}

\section{Sekilas Profil Front Pembela Islam}

Pada peringatan kemerdekaan Indonesia ke-53, tanggal 17 Agustus 1998, sejumlah tokoh yang terdiri dari ustadz, kyai, dan ulama yang kebanyakan berasal dari Jabotabek, berkumpul di pesantren al-Umm, Ciputat, Tangerang. Pertemuan ini dimaksudkan untuk memperingati dan mensyukuri kemerdekaan Indonesia sekaligus untuk membahas berbagai isu yang terjadi di masyarakat, mulai dari ketidakadilan hingga hak asasi manusia, yang sebagian besar korbannya adalah umat Islam. Di antara yang hadir adalah K.H. Cecep Bustomi (putra anak kiai kondang di daerah Banten, KH Bustom), Habib Idrus Jamalullail (nama lengkapnya, Habib Fachry bin Idrus Jamalullail, Mubalig dan Imam Besar Masjid Nurul Abrar Jakarta), K.H. Damanhuri (Mubalig dan Pimpinan Pesantren al-Karimiah, Sawangan Baru Kota Depok), Habib Muhammad Rizieq Syihab (Imam Besar PFI sejak didirikan sampai sekarang), dan K.H. Misbahul Anam (Muqaddam Tarekat Tijanni dan Pimpinan Pondok Pesantren Al-Umm, Ciputat, Jakarta Selatan), sebagai tuan rumah. Dalam pertemuan tersebut, muncul sebuah kesepakatan untuk membentuk forum yang akan mengakomodasi aspirasi masyarakat serta untuk menemukan solusi terbaik untuk berbagai problematikan tersebut. Pertemuan tersebut selanjutnya dipandang sebagai hari jadi Front Pembela Islam/FPI (Jamhari, 2004: 129-130).

Nama "Front Pembela Islam" disepakati oleh para ulama yang hadir di Pesantren Al-Umm, karena nama ini diyakini memiliki arti tersendiri dari setiap katanya. Menurut Jamhari (2004) kata "Front" menegaskan bahwa organisasi ini akan selalu berusaha menjadi organisasi yang terdepan dan memiliki sikap tegas dalam setiap langkah perjuangannya dalam menegakkan amar ma'ruf nahi munkar. 
Kata "Pembela" menyiratkan bahwa organisasi ini akan selalu berperan aktif dalam membela dan memperjuangkan hak-hak Islam dan umat Islam setiap kali dirugikan atau dizalimi. Sedangkan kata "Islam" mencirikan bahwa perjuangan organisasi ini tidak lepas dari ikatan ajaran Islam yang memiliki karakter lurus dan benar. Dengan nama "Front Pembela Islam", organisasi tersebut berkomitmen untuk mempertahankan "nilai" dan "ajaran", bukan orang atau kelompok tertentu. Hal itu mengandung arti, seperti dikatakan Habib Rizieq, pendiri dan ketua FPI, bahwa FPI sangat mungkin membela kelompok nonMuslim, khususnya yang teraniaya atau membutuhkan bantuan umat Islam karena membantu mereka merupakan salah satu bagian dari ajaran Islam (Jamhari 2004: 132-133).

Kondisi sosio-politik di balik berdirinya atau menjadi latar pendirian FPI dirumuskan oleh para aktivis pendiri gerakan ini, yaitu: pertama, penderitaan yang dialami oleh umat Islam Indonesia sebagai akibat pelanggaran hak asasi manusia yang dilakukan oleh pihak berwenang; kedua, ada kewajiban bagi setiap muslim untuk menjaga harkat dan martabat Islam dan kaum muslimin. Ketiga, ada kewajiban bagi setiap muslim untuk bisa menegakkan amar ma'rüf nabi munkar.

Sementara itu, salah satu tujuan didirikannya FPI adalah melakukan amar ma'rüf nahi munkar. Dalam menegakkan amar ma'rüf, FPI ternyata lebih mengutamakan metode yang bijaksana dan lembut melalui langkah-langkah mengedepankan metode hikmah, (kebijaksanaan dan kelembutan) dalam menyampaikan nasihat yang baik (mau'rzhah hasanah), dan mendiskusikannya dengan cara terbaik. Adapun dalam melakukan dan mengaplikasikan nabi munkar, FPI mengutamakan sikap lugas dan tegas yang dipraktikkan antara melalui penggunaan kekuatan saat mampu melakukan yang tercermin dalam ketegasan sikap dalam konteks tidak menyetujui terlebih mendukung bentuk apapun dari perbuatan munkar (Aditiya, 2003).

Orientasi Organisasi FPI terletak pada aksi dan gerakan, sehingga tidak terlalu memperhatikan format dan bentuk institusi organisasi. Begitu pula mekanisme organisasi tidak ditentukan secara rinci dan standar baku, namun diatur secara temporal dan kondisional sesuai dengan kebutuhan pergerakan di lapangan. Oleh karena itu, pemimpin gerakan memiliki wewenang penuh untuk mengambil kebijakan dan menentukan arah pergerakan kelompok ini. Namun demikian, jika dilihat secara umum, struktur organisasi di FPI dibagi menjadi tiga bagian, yaitu: struktur utama, pusat dan daerah, dan struktur komando pos.

Azas FPI adalah Islam Ablussunah wal Jamaah (Aswaja) yang secara umum diartikan sepakat untuk berpegang dengan kebenaran pasti sebagaimana tertera dalam Alquran dan al-hadits dan dipraktekkan oleh para sahabat dan tabi'in. Aswaja merupakan identitas teologis yang diperebutkan oleh berbagai aliran maupun organisasi Islam. Aswaja dianut oleh NU, sebagaimana terdapat dalam Anggaran Dasarnya. Aswaja juga diklaim sebagai salah satu keputusan Majelis 
Tarjih Muhammadiyah meskipun menggunakan redaksi yang agak berbeda yaitu Abl al-Haq wa al-Sunnab: Persatuan Islam (PERSIS) juga menyatakan diri lebih berhak menyandang sebutan Abl al-Sunnah wa al-Jama'ah daripada NU karena PERSIS selalu berusaha menghilangkan bid'ah dalam agama serta melaksanakan ajaran Islam yang sebenarnya. Kata Aswaja juga menjadi nama sebuah organisasi paramiliter yaitu Laskar Jihad Ahlussunnah wal Jama'ah yang dipimpin oleh Umar Ja'far Thalib yang sekarang telah bubar (Qomar, 2014: 163). Azas Aswaja menurut FPI lebih cenderung sama dengan Aswaja versi Umar Ja'far Thalib yang bercorak radikal.

Jika dilihat dari latar belakang pendiriannya, jelas sekali bahwa FPI mempunyai sudut pandang yang sekaligus menjadi kerangka berfikir organisasi (visi), bahwa penegakan amar ma'ruf nahi munkar adalah satu-satunya solusi untuk menjauhkan kezaliman dan kemunkaran. Tanpa penegakan amar ma'ruf nahi munkar, mustahil kezaliman dan kemunkaran akan sirna dari kehidupan umat manusia di dunia. Tidak mengherankan jika beragam aksi yang dilakukan FPI kerap kontroversial karena tidak sejalan dengan norma yang ada. Bahkan, banyak yang memandang FPI sebagai simbol perilaku kekerasan dalam mendakwahkan agama.

Namun demikian, secara obyektif harus disebut pula bahwa disamping aksi-aksi kontroversial yang kerap mereka lakukan, FPI juga banyak melibatkan diri dalam aksi-aksi kemanusiaan antara lain pengiriman relawan ke daerah bencana tsunami di Aceh, bantuan relawan dan logistik saat bencana gempa di Padang dan beberapa aktivitas kemanusiaan lainnya (Faiz, 2014: 357).

\section{Hakikat Dakwah dan Amar Ma'rūf Nahī Munkar Perspektif FPI}

Perbedaan pemahaman makna dakwah berkaitan erat dengan hakikat dakwah dan pemahaman esensi Islam (Sukayat, 2012: 205). Demikian juga dengan pemahaman dakwah FPI berkaitan dengan hakikat dakwah dan pemahaman mereka tentang ajaran Islam.

Hakikat dakwah perspektif FPI tidak berbeda dengan makna dakwah yang

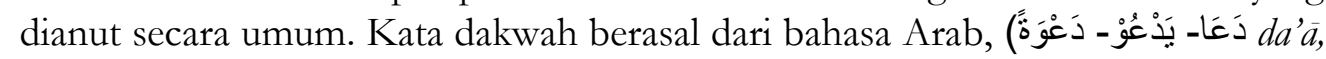
yad'ü, da'watan, yang bermakna seruan, panggilan, undangan atau do'a. Sedangkan menurut istilah, dakwah adalah upaya memanggil, menyeru dan mengajak manusia menuju Allah (QS. Yusuf [12]: 108). Ajakan kepada Allah dimaksud berarti ajakan kepada agama-Nya, yaitu al-Islam (QS. Ali-'Imran [3]: 104). Seruan kepada al-khayr menurut para mufassir adalah al-Islam dalam arti yang seluasluasnya yaitu agama semua nabi sepanjang zaman. Atas dasar itu, dakwah pada hakikatnya adalah proses islamisasi.

Orientasi dan urgensi dakwah dalam pandangan al-Mawardi (1939: 258) secara umum dakwah adalah mendorong umat manusia menegakan kebaikan dan menekan perbuatan munkar, yang merupakan urusan keagamaan (al-qawä'id al-diniyah). Urgensi dakwah, dalam pandangan Shaikh 'Ali Mahfudh dalam 
Hidàyat al-Murshidīn (Mahfūdh, 1987: 10), adalah upaya membangkitkan kesadaran manusia di atas kebaikan dan bimbingan, menyuruh berbuat ma'rüf dan mencegah perbuatan munkar supaya mereka mendapat kebahagiaan di dunia dan akhirat.

Sedangkan orientasi dan tujuan dakwah secara sosio-theologis, menurut Kuntowijoyo (2006: 96) berdasarkan tafsir Surat Ali Imran [3]: 110, bahwa terdapat empat tujuan dakwah yang sekaligus menjadi dasar-dasar ilmu sosial profetik yakni: (1) konsep tentang ummat terbaik; (2) aktivisme sejarah, (3) pentingnya kesadaran, dan (4) etika profetik. Pertama, konsep tentang ummat terbaik. Menurut Kuntowijoyo Umat Islam menjadi ummat terbaik dengan syarat melakukan tiga tindakan nyata, yaitu menyuruh pada ma'rüf, mencegah yang munkar dan beriman kepada Allah. Dengan demikian konsep ummat terbaik dalam Islam adalah berupa tantangan untuk bekerja lebih baik ke arah aktivisme sejarah. Kedua, aktivisme sejarah. Bekerja di tengah-tengah manusia (ukbrijat li-alnàs) berarti bahwa yang ideal bagi Islam adalah keterlibatan umat dalam sejarah. Islam, bagi Kuntowijoyo, adalah agama amal. Ketiga pentingnya kesadaran. Nilainilai Ilahiah (ma'rüf, munkar, iman) menjadi tumpuan aktivisme Islam. Peranan kesadaran ini bagi Kuntowijoyo membedakan etika Islam dari etika materialistis. Pandangan Marxis menyatakan bahwa kesadaran (superstruktur) ditentukan oleh basis sosial atau kondisi materi (struktur), sementara Islam menyatakan kesadaranlah yang mengarahkan kondisi realitas. Keempat, etika profetik yaitu melakukan humanisasi (amar ma'rüf), liberasi (nabi munkar), dan transendensi. (Kuntowijoyo, 2006: 97).

Tujuan bumanisasi adalah memanusiakan manusia dari situasi apapun yang hendak mendehumanisasi termasuk dari ilmu, teknologi atau pemahaman agama tertentu. Tujuan liberasi adalah pembebasan bangsa dari kekejaman kemiskinan, keangkuhan teknologi, dan pemerasan kelimpahan. Sedang tujuan Transendensi adalah menambahkan dimensi transendental dalam kebudayaan. Saat ini manusia modern menerah kepada arus hedonisme, materialisme, dan budaya yang dekaden (Kuntowijoyo, 2008: 484). Saatnya manusia percaya bahwa sesuatu harus dilakukan, yaitu membersihkan diri dengan mengingatkan kembali dimensi trasnsendental yang menjadi bagian sah dari fitrah kemanusiaan.

Dalam menyampaikan dakwah amar ma'rüf nabi munkar, para dai dituntut memiliki rasa tanggung jawab yang tinggi, baik kepada Allah maupun masyarakat dan negara. Bertanggung jawab kepada Allah dalam arti bahwa dakwah yang ia lakukan harus benar-benar ikhlas dan sejalan dengan apa yang telah digariskan oleh Alquran dan Sunnah. Bertanggung jawab kepada masyarakat atau umat menganduang arti bahwa dakwah Islamiyah memberikan kontribusi positif bagi kehidupan sosial umat yang bersangkutan. Bertanggung jawab kepada negara mengandung arti bahwa pengemban risalah senantiasa memperhatikan kaidah hukum yang berlaku di negara dimana ia berda'wah. Jika dakwah dilakukan tanpa meng-indahkan hukum positif yang berlaku dalam sebuah negara, maka 
kelancaran dakwah itu sendiri akan terhambat dan bisa kehilangan simpati dari masyarakat.

Disamping itu, dalam Alquran diisyaratkan bahwa dakwah kepada al-Isläm bermakna mengajak segenap umat manusia meyakini dan mengamalkan al-Isläm secara kaffah (QS. al-Baqarah [2]: 208). Sedangkan yang dimaksud al-Isläm käffah adalah tercapainya isi, substansi dan essensi ajaran al-Islam itu sendiri, yaitu alIslam yang secara theologis berarti ajaran untuk berserah diri hanya kepada Allah serta mengikuti segala sistem dan ajaran-Nya serta menjauhi segala larangan-Nya. Serta al-Isläm yang secara sosiologis, mampu memberikan kedamaian (saläm), dan kesejukan (silamm) serta kesejahteraan dan kesentosaan (salämah), bahkan tercapainya peningkatan kualitas hidup yang utuh dan konprehensif bagi umat manusia di dunia dan akhirat (sullam) (Amshari, 1995).

Lebih lanjut dalam al-Qur'ān dijumpai lafaz "amr ma'rüf nahi munkar" pada beberapa tempat, diantaranya terdapat dalam QS. Ali Imrān [3]:104, yang menyatakan bahwa hendaklah ada di antara kamu ada segolongan orang yang menyeru kepada kebajikan, menyuruh (berbuat) yang ma'rüf, dan mencegah dari yang munkar.

Lafaz amar ma'rüf dan nabi munkar tersebut juga bisa ditemukan dalam QS. Ali Imrān [3]: 110; al-Taubah [9];71; al-Haji [22]: 41; al-A'raf [7]: 165; al-Maidah [5]: 78-79 serta masih banyak lagi dalam surat yang lain. Dengan mencermati bebErapa ayat-ayat ini, dapat dipahami bahwa amar ma'rüf nabi munkar merupakan perkara yang benar-benar urgen dan harus diimplementasikan dalam realitas kehidupan masyarakat.

Secara global ayat-ayat tersebut menganjurkan terbentuknya suatu kelompok atau segolongan umat yang intens mengajak kepada kebaikan dan mencegah dari kejelekan. Kelompok tersebut bisa berupa sebuah organisasi, badan hukum, partai ataupun hanya sekedar kumpulan individu-individu yang sevisi.. Anjuran tersebut juga dikuatkan dengan hadits Rasulullah: "Jika kamu melihat umatku takut berkata kepada orang zalim, 'Hai zalim!', maka ucapkan selamat tinggal untuknya."

Dari ayat-ayat di atas dapat ditangkap bahwa amar ma'rüf dan nabi munkar merupakan salah satu parameter yang digunakan oleh Allah dalam menilai kualitas suatu umat (Fajar, 2005: 13). Ketika mengangkat kualitas derajat suatu kaum ke dalam tingkatan yang tertinggi Allah berfirman: "Kamu (umat Islam) adalah umat terbaik yang dilabirkan untuk manusia." Kemudian Allah menjelaskan alasan kebaikan itu pada kelanjutan ayat: " (Karena kamu) menyurub (berbuat) yang makrüf dan mencegah dari yang munkar." (QS. Ali Imrān [3]: 110).

Bila kandungan ayat-ayat amar ma'rüf nabi munkar dicermati,-terutama ayat 104 dari Surah Ali Imrān [3] dapat diketahui bahwa Lafaz amar ma'rüf dan nabi munkar lebih didahulukan dari lafaz iman, padahal iman adalah sumber dari segala keta'atan. Hal ini dikarenakan amar ma'rüf nabi munkar adalah bentengnya 
iman, dan hanya dengannya iman akan terpelihara. Di samping itu, keimanan adalah perbuatan individual yang akibat langsungnya hanya kembali kepada diri si pelaku, sedangkan amar ma'rüf nahi munkar adalah perbuatan yang berdimensi sosial yang dampaknya akan mengenai seluruh masyarakat dan juga merupakan hak bagi seluruh masyarakat.

Dengan demikian, pokok dari amar ma'rüf adalah mengesakan Allah, Tuhan semesta alam. Sedangkan pokok dari nabi munkar adalah mencegah syirik kepada Allah. Implementasi amar ma'rüf nabì munkar ini pada dasarnya sejalan dengan pendapat khalayak yang dalam bahasa umumnya disebut dengan public opinion, sebab al-ma'rüf adalah apa-apa yang disukai dan diingini oleh khalayak, sedang al-munkar adalah segala apa yang tidak diingini oleh khalayak. Namun kelalaian dalam ber-amar ma'rüf telah memberikan kesempatan bagi timbulnya opini yang salah, sehingga yang ma'rūf terlihat sebagai kemunkaran dan yang munkar tampak sebagai hal yang ma'rūf.

Sedangkan tujuan dan target dakwah yang ditunjukkan al-Quran dan hadith Nabi Saw., sedikitnya ada dua, yaitu: Pertama, melepas beban tanggung jawab menegakkan bujjah (penjelasan) kepada objek dakwah (mad'u). Sebagaimana diungkapkan Ibnu Taymiyyah (1983: 142) bahwa sungguh Allah menegakkan bujjah-nya kepada para makhluk dengan para rasul yang diutus sebagai pemberi kabar gembira dan peringatan (QS. An-Nisa ayat [4]:165). Kedua, mengharap petunjuk bagi orang yang didakwahi. Ini dapat dilihat dari sirah Nabi dan dijelaskan langsung oleh Allah dalam banyak ayat-Nya (QS. An-Nahl [16]:37).

Dakwah dan amar ma'rüf nahi munkar dengan metode yang tepat akan menghantarkan dan menyajikan ajaran agama secara sempurna. Metode yang diterapkan dalam menyampaikan amar ma'rüf nahì munkar tersebut sebenarnya akan terus berubah-ubah sesuai dengan kondisi masyarakat yang dihadapi para dā'i. amar ma'rüf dan nabì munkar tidak bertujuan memperkosa fitrah seseorang untuk tunduk dan mengikuti tanpa mengetahui bujjah yang dipakai, tetapi untuk memberikan koreksi dan membangkitkan kesadaran dalam diri seseorang akan kesalahan dan kekurangan yang dimiliki (As-Sadr, 2003: 156).

Bagi FPI untuk menjadi umat terbaik, kaum muslim harus menjalankan dakwah melalui amar ma'rüf nabi munkar (menyeru kebaikan dan mencegah kemunkaran). Sehingga kemudian, langkah yang ditempuh FPI untuk menciptakan masyarakat religius adalah dengan cara amar ma'rüf nahi munkar. Bagi FPI amar ma'rüf nahi munkar tidak dapat dipisahkan. Jika hanya menegakkan amar ma'rüf atau nahi munkar saja, cita-cita untuk menjadikan masyarakat yang religius tidak akan pernah tercapai (Jamhuari, 2004: 141-142).

FPI selalu mendasarkan gerakannya pada apa yang mereka sebut: Tri Tuntutan Laskar FPI". Ketiga tuntutan itu adalah; (1) Semua iklan maksiat di tempat-tempat umum harus dilarang, (2) Semua tempat yang secara terang-terangan menjadi sarang maksiat harus ditutup total, dan (3) semua 
tempat yang diduga kuat menjadi sarang maksiat harus ditutup pada harihari besar Islam khususnya dan umumnya pada hari besar umat beragama, bila terbukti menjadi sarang maksiat harus ditutup total. Oleh karena itu FPI selalu mengklaim dirinya sebagai "gerakan anti maksiat".

Habib Rizieq Shihab memaknai ayat-ayat amar ma'rüf dan nabi munkar sebagai kewajiban setiap muslim. Menurutnya, jika aksi amar ma'rǘ nabì munkar ingin diterapkan, maka aksi dan gerakan amar ma'rüf dan nahi munkar tidak bisa dihindari, atau dengan kata lain harus menggunakan kekerasan. Dengan kata lain, Front Pembela Islam (FPI) telah mengusung misi, bahwa harus ada gerakan yang berani melawan praktek-praktek kemunkaran dan kemaksiatan secara prontal. Inilah warna gerakan FPI, dimana pihak-pihak yang tidak suka, memanggilnya "kelompok radikal" (Thalkhah, 2005: 158).

Pemahaman tersebut, jika dikaji secara seksama, pada dasarnya Habib Rizieq dan FPI tidak salah dalam memahami dan mencanangkan visi amar ma'rüf nabi munkar, merancang segala macam aktifitas sebagai misi dalam rangka menyukseskan visi dimaksud sebab, setiap muslim hakikatnya memiliki kewajiban yang sama untuk melakukan amar ma'rüf nabì munkar. Namun, perlu dipahami pula bahwa strategi pemaksaan dan kekerasan yang dilakukan FPI tampaknya perlu dikaji ulang sampai ditemukan formula aksi yang tepat dalam amar ma'rüf nabi munkar, tanpa harus melibatkan kekerasan. Mereka tentu memahami pula bahwa banyak ayat al-Qur'an dan hadis yang menyatakan bahwa tugas seorang muslim kepada muslim yang lain adalah 'saling mengingatkan', 'saling bekerja sama', 'saling menasehati', tanpa harus memaksakan hasil, apalagi dengan kekerasan. Bahkan Nabi pun menyatakan bahwa yang bisa dilakukannya hanyalah "mengajak dan memperingatkan", sementara hidayah dan keterbukaan hati adalah hak prerogratif Allah (Faiz, 2014: 363).

Ketegasan dalam menyampaikan amar ma'rüf dan nabi munkar bukan berarti menghalalkan cara-cara yang radikal. Implementasinya harus dengan strategi yang halus dan menggunakan metode tadarruj (bertahap) agar tidak menimbulkan permusuhan dan keresahan di masyarakat. Penentuan strategi dan metode amar ma'rüf nabi munkar harus mempertimbangkan kondisi sosial masyarakat yang dihadapi. Jangan sampai hanya karena kesalahan kecil dalam menyampaikan amar ma'rǘ nabì munkar justru mengakibatkan kerusakan dengan social cost yang tinggi (Mahmūd, 1995: 166).

\section{Akar Dakwah Hisbah di Indonesia Perspektif FPI}

FPI memiliki kekhasan dalam memperjuangkan nilai-nilai Islam melalui konsep dakwah bisbah. Menurut Habib Muhammad Rizieq Shihab medan juang Islam terdiri dari tiga bagian, yakni: dakwah, hisbah, dan jihad. Ketiga medan juang ini menurutnya jangan dibenturkan tapi wajib disinergikan. Medan juang hisbah adalah upaya menegakkan amar ma'rüf nahi munkar (Shihab, 2008: 46),

Kata hisbah secara etimologi berasal dari akar kata Bahasa Arab hasaba- 
yahsubu yang berarti "menghitung" dan "membilang" (Yunus, 1989: 102). Secara istilah, hisbah adalah memerintahkan kebaikan apabila ada yang meninggalkannya, dan melarang kemunkaran apabila ada yang melakukannya (al-Haritsi, 2003: 587).

Pengertian lain tentang hisbah dikemukan oleh beberapa ulama sebagaimana dirangkum oleh Sukamto (2016: 60-61). Al-Mawardi dan Ibn Taimiyah mendifinisikan hisbah sebagai lembaga yang mempunyai wewewang untuk menegankkan amar ma'rüf nabi munkar yang bukan termasuk wewenang umara (penguasa). Sementara itu, menurut Ibn Khaldun hisbah merupakan institusi keagamaan yang termasuk bagian dari amar ma'rüf nabì munkar yang merupakan kewajiban bagi seluruh kaum muslimin. Definisi tersebut sangat umum terkait dengan masalah sosial ekonomi dan agama. Definisi yang lebih spesifik dikemukakan oleh Rofiq Yunus al-Mishri, hisbah adalah petugas yang bertugas mengawasi pasar serta tingkah laku masyarakat (Sukamto, 2016: 60-61).

Berdasarkan definisi ini, setidaknya ada tiga poin penting mengenai hisbah, yaitu: a) bisbah adalah institusi atau lembaga yang secara khusus dibentuk oleh pemerintah; b). tugas utama hisbah adalah amar ma"ruf nabi munkar, c) tugas khusus hisbah adalah mengawasi berbagai kegiatan ekonomi di pasar, menjaga mekanisme pasar supaya berjalan normal, dan tidak terdistorsi serta melakukan tindakan korektif ketika terjadi distorsi pasar (Sukamto, 2016: 61).

Dalam terminologi hukum Islam, kata bisbah juga sering digunakan bersamaan dengan kata "wilayah" yang berarti "pemerintahan", "kekuasaan" dan "kewenangan" (Ma'luf, 1989: 919) sehingga susunannya menjadi "wilayat alhisbab" atau kewenangan hisbah. Dalam mendefinisikan wilayah hisbah, ada beberapa pendapat. Ibnu Taimiyyah menyatakan bahwa yang dimaksud dengan wilayah hisbah adalah mubtasib yang kewenangannya adalah menyuruh berbuat baik dan melarang berbuat munkar, yang tidak termasuk wilayah qadha dan wilayah lainnya (al-Asimi, 1984: 69). Mubtasib adalah orang yang dipercaya dan ditunjuk untuk mengawasi pasar agar nilai-nilai moral dilaksanakan (Lewis, 1971: 485). Pada dasarnya hisbah mencakup semua aspek kehidupan (al-Haritsi, 2003: 588) dan berkaitan dengan masalah moral dan kesusilaan. Diantara bidang-bidang yang menjadi kekuasaan hisbah atau muhtasib yaitu memegang kekuasaan eksekutif, hukum dan kepolisian. (Mujahidin, 2012).

Dengan kata lain, hisbah merupakan lembaga penegak hukum yang bertugas melaksanakan amar ma'rüf nahì munkar dengan wewenang tersendiri di luar wewenang qadhâ, maz̧hâlim, maupun lembaga lainnya. Penjabaran dari tanggung jawab tersebut dapat diklasifikasikan menjadi tiga macam: pertama, tanggung jawab yang berkaitan dengan hak-hak Allah, yaitu pengawasan terhadap masyarakat dan memfasilitasi aktivitas keagamaan mereka seperti memerintahkan salat lima waktu, salat Jumat, salat 'Id, dan pemeliharaan masjid. Kedua, tanggung jawab yang berkaitan dengan hak-hak manusia yaitu menaruh perhatian besar terhadap implementasi prinsip keadilan dalam masyarakat, 
seperti pengawasan terhadap akurasi timbangan dan takaran, serta inspeksi harga dan barang di pasar. Ketiga, tanggung jawab yang berkaitan dengan hak-hak Allah dan manusia yaitu pengawasan terhadap administrasi dan pelayanan umum, seperti memelihara kondisi jembatan, kebersihan jalan raya, mengadakan ronda, dan tindakan preventif terhadap pelbagai fasilitas umum agar tetap terpelihara dengan baik (Taymiyyah, 1983: 142).

Tradisi hisbah telah diletakkan langsung pondasinya oleh Rasulullah saw. Beliaulah mubtasib (pejabat yang bertugas melaksanakan hisbab) pertama dalam Islam. Rasulullah sering keluar masuk pasar Madinah mengawasi aktivitas jual beli. Suatu ketika Rasulullah mendapati seorang penjual gandum berlaku curang dengan menimbun gandum basah dan meletakkan gandum yang kering di atasnya, beliau memarahi penjual tersebut dan memerintahkan untuk berlaku jujur, "barangsiapa yang menipu maka ia tidak termasuk golongan kami," ungkapnya (Islahi, 1996).

Rasulullah setiap hari memantau pelaksanaan syari'at oleh masyarakat Madinah. Setiap pelanggaran yang tampak olehnya langsung mendapat teguran disertai nasihat untuk memperbaikinya. Pada masa Nabi, wewenang dan tugas hisbah memang belum berbentuk sebuah institusi atau lembaga peradilan tersendiri, namun masih dijalankan langsung oleh Nabi. Pada saat itu sudah terlihat bahwa Nabi memerintahkan seseorang untuk mengawasi dan menghakimi (menjadi qadhi) dalam sebuah daerah, seperti penunjukan Muadz Ibn Jabal (Solikhin, 2005:44). Contoh yang diberikan oleh Nabi Muhammad Saw. itu selanjutnya diteruskan oleh para Khulafa' al-Rasyidin (Islahi, 1996: 188).

Pada masa ini secara struktural hisbah belum ada perubahan signifikan seperti pada masa Nabi. Para khalifah terjun langsung untuk menjalankan peran bisbah, salah satunya mengawasi perekonomian. Hanya pada masa Khalifah Umar Ibn Khattab telah ada semacam pelembagaan atau pengangkatan yang lebih sempurna dibandingkan pada masa sebelumnya. Khalifah Umar melantik dan menetapkan wilayah hisbah sebagai bagian dari kekuasaan departemen dalam pemerintahan yang resmi.

Selanjutnya pada masa Daulah Umayyah wilayah hisbah telah mengalami perkembangan yang lebih luas. Pada masa inilah wilayah bisbah telah dibentuk menjadi sebuah kewenangan peradilan tersendiri yang terpisah dari pemerintahan khalifah. Lembaga hisbah menjadi salah satu lembaga peradilan yang ada dengan kewenangan mengatur dan mengontrol pasar dari perbuatan-perbuatan yang tidak sesuai dengan syari'at Islam (Islahi, 1996: 188). Menurut sebagian pendapat penamaan resmi lembaga hisbah dan penyebutan istilah mubtasib untuk menunjuk orang yang bertugas menjalankan hisbah baru mulai dikenal pada masa Khalifah Al-Mahdi pada masa dinasti Abbasiyah). Wilayah hisbah seterusnya tetap eksis di sebagian besar negara muslim hingga permulaan abad ke-20-an (Islahi, 1996: 189).

Dalam perspektif FPI, gerakan Amar ma'rūf nahi munkar (bisbah) di 
Indonesia sudah dimulai bersamaan dengan masuknya Islam ke Nusantara pada awal abad kedua Hijriyyah/kedelapan Miladiyyah, yang kemudian melahirkan kerajaan Islam Perlak di Aceh pada tanggal I Muharram $225 \mathrm{H}$ di bawah pimpinan Sultan Alāiddin Sayyid Maulana 'Abdul 'Azîz Syāh (Shihab, 2008). Para Walisongo yang hidup sekitar akhir abad 14 M hingga awal abad 15 M, telah melaksanakan hukuman mati terhadap Syeikh Siti Jenar sebagai bentuk penegakan Syari'at Islam dalam pelaksanaan hukum hudūd terkait masalah $A r$ Riddah (kemurtadan). Menurut Shihab (2008), hukum had tersebut merupakan tonggak sejarah bagi penegakan hukum pidana Islam di bumi Indonesia. Bahkan menurutnya, di Indonesia jauh sebelum kedatangan para penjajah, telah berdiri berbagai Kesultanan Islam yang menjadikan Islam sebagai agama negara dan syari'atnya sebagai hukum negara. Semangat amar ma'rüf nahi munkar dalam penegakan syari’at Islam di Indonesia telah mampu mendorong kaum muslimin Indonesia untuk mengobarkan perlawanan terhadap para penjajah. Menurut Shihab (2008), sejumlah bukti historis keterkaitan perjuangan mereka dengan pergerakan Islam, antara lain terjadinya perang Palembang (1658 - $1851 \mathrm{M})$, perang Bone (1814 - $1946 \mathrm{M})$, perang Paderi (1821 - $1837 \mathrm{M})$, perang Diponegoro $(1825-1830 \mathrm{M})$, perang Aceh $(1873$ - 1942) dan perang Riau (1782 - 1784 M) (Anwar, 2015).

Menurut Habib Rizieq, amar ma'rüf itu berbentuk seruan dan instruksi yang tegas kepada masyarakat untuk berbuat kebaikan. Nabi Saw. ketika menyampaikan amar ma'rüf bak komando pasukan tempur, suaranya lantang dan matanya sampai terlihat memerah. "Mengajak anak shalat, mentradisikan mematikan televisi saat Maghrib, melarang untuk merokok adalah bentuk amar maruf. Karena itu orang tua harus memberi teladan" (Shihab, 2008).

Pemahaman tentang hisbah yang dikemukan Habib Muhammad Rizieq Syihab ternyata dianut dan diikuti oleh para pengurus, anggota dan simpatisan PFI. Seperti dinyatakan oleh Agus salah seorang simpatisan FPI wilayah Purwakarta (wawancara, 5 Januari 2018), "Habib Muhammad Rizieq Syihab adalah imam FPI, sehingga pendapatnya bahwa hisbah adalah upaya menegakkan amar ma'rüf nahi munkar, itulah pendapat yang kami ikuti". Pemahaman bisbah yang dianut oleh FPI dengan makna yang tidak sesuai dengan amar ma'rüf nabi munkar yang menjadi ladang subur tumbuhnya radikalisme di Indonesia.

Dalam Ensiklopedi Nasional Indonesia Jilid 14 (1994: 73), radikalisme berarti aliran yang ekstrem, fundamental, atau mengakar. Tanda-tanda perilaku ekstrem menurut Yusuf Qardhawi (dalam Nasution, 1988: 16-2-) ditandai dengan ciri-ciri sebagai berikut : Pertama, fanatik pada satu pendapat dan menutup diri dari yang lain. Fanatik adalah orang yang tidak melihat selain dirinya, tidak mendengar kecuali ucapannya sendiri, tidak percaya pada orang di luar kelompok jamaah tempat ia berafiliasi, cenderung menutup pikiran dan dirinya dari yang lain, serta menganggap manusia sebagai yang lain di luar diri maupun kelompoknya. Kedua, mewajibkan sesuatu yang sebenarnya tidak wajib. Hal ini tampak dalam hal 
pemahaman terhadap sesuatu hal yang sebenarnya tidak wajib, karena merasa ia taat sesuatu yang tidak wajib menjadi wajib dan harus dilakukan, termasuk di antaranya perbuatan yang memberatkan adalah memaksakan orang lain mengerjakan hal-hal yang sunnah, dengan menganggapnya seolah-olah wajib, dan menganggap yang makruh seolah-olah haram.

Ketiga, memperberat yang tidak pada tempatnya. Memperberat yang tidak dibenarkan adalah meletakkan sesuatu pada proporsi yang tidak sesuai dengan tempat dan zamannya, seperti melakukannya di suatu negara yang bukan Islam dan bukan negara asal Islam atau orang yang baru bertobat. Keempat, sikap kasar dan keras. Ciri ini bertentangan dengan petunjuk Allah dan Rasulullah. Allah telah memerintahkan manusia agar mengajak kepada agama-Nya dengan hikmah kebijaksanaan, bukan dengan kejahilan; dengan pengajaran yang baik, bukan dengan ungkapan-ungkapan kasar, serta berdebat dengan cara yang paling baik.

Kelima, sikap buruk sangka. Sikap ini seperti mencurigai kelompok penganut agama lain dan menuduh mereka melakukan kecurangan dalam menyebarkan misi agamanya. Hal ini menjadi peluang bagi kelompok yang curiga untuk menanggapinya melalui cara-cara yang mengarah kepada kekerasan. Keenam, saling mengkafirkan. Akibat berpedoman secara fanatik kepada satu pendapat memudahkan seseorang memandang kelompok yang tidak sejalan sebagai kafir. Sikap ini ciri dari kaum khawarij, yang mudah mengkafirkan seseorang yang tidak segolongan, meskipun orang tersebut orang Islam (Nasution, 1988: 125).

Pemahaman FPI memiliki kesamaan dengan tanda-tanda perilaku ekstrem menurut Yusuf Qardhawi di atas, yaitu FPI fanatik pada satu pendapat khususnya pendapat pimpinannya dan menutup diri dari pendapat yang lain dan FPI bersikap kasar dan keras ketika melakukan dakwah di masyarakat khususnya dalam mencegah kemunkaran.

\section{Ketidaksesuaian Dakwah FPI dengan Makna Hisbah}

Pemahaman FPI tentang hisbah yang telah di bahas di atas bila dianalisis lebih lanjut ternyata mengandung ketidaksesuaian dengan pemahaman tentang hisbah menurut pemahaman para ulama. Berdasarkan konteks waktu jika dikaji perjuangan para pendahulu Islam di Indonesia dalam menegakkan akidah (amar ma'rüf nahi munkar), khususnya pada rentang tahun 1600 - 1800 tampaknya berbeda dengan aksi FPI yang dilakukan pada konteks sekarang. Zaman dulu bangsa Indonesia berada dalam belenggu penjajahan yang tidak memberikan kebebasan kepada umat Islam untuk beraktivitas dan mengamalkan ajaran Islam, sehingga umat Islam yang dipimpin para kyai bangkit sekaligus untuk memperjuangkan kemerdekaan bangsa dari penjajahan.

Dalam konteks ilmu dakwah sebagaimana dibahas di atas, bahwa FPI, merupakan organisasi Islam pasca reformasi yang konsisten dengan visi dan misinya: "Amar ma'rüf dan nabi munkar. Namun FPI memaknainya harus dengan 
kekerasan, mengacu kepada Hadist Nabi: "Bilyadi", terutama dalam menegakkan nabi munkar. Namun jika ditelaah lebih lanjut tentang makna bilyadi, ada yang memaknai berbeda walaupun sama-sama dari kalangan Sunni, misalnya bilyadi dimaknai dengan kekuasan, artinya dakwah Amar ma'rüf an nahì munkar itu tidak hanya di lapangan terbuka, tetapi juga di panggung politik, apakah sebagai pejabat eksekutip, legislatif maupun yudikatif (Rosadi, 2003).

Lebih jauh, bahwa meskipun amar ma"ruf nabi munkar mampu mendatangkan maslahat dan mampu menolak mafsadah, pelaksanaannya harus tetap mempertimbangkan kerugian yang ditimbulkan. Jika kemaslahatan berkurang atau kerusakan yang ditimbulkan lebih besar maka dalam kondisi seperti itu amar ma'ruf nabi munkar tidak dianjurkan. Sementara yang menjadi tolak ukur maslahat dan mafsadah adalah syariat. Jika kerusakan dan kerugian lebih banyak maka bukan termasuk perkara yang diperintahkan meskipun konsekuensinya harus meninggalkan yang diwajibkan atau melanggar yang diharamkan, karena yang wajib bagi seorang mukmin hanya bertaqwa kepada Allah dalam memerintahkan hamba Allah (yang lainnya), tidak dituntut untuk memberi hidayah (Abidin, 2009: 186).

Selain itu, dalam konteks hukum di Indonesia, FPI merupakan kelompok subculture deviance yang melakukan perbuatan-perbuatan yang melanggar normanorma legal yang berlaku dalam masyarakat. Sebab, walaupun mayoritas penduduk Indonesia beragama Islam, namun tidak sepenuhnya menganut nilai dan norma agama Islam. Yang membuat FPI menjadi radikal adalah ketika citacita bagi terlaksananya kehidupan seperti itu ditempuh dengan menggunakan kekerasan dan cara-cara yang drastis. Kekerasan dan cara-cara drastis itu kadangkadang menimbulkan ketakutan pada diri banyak orang serta dapat pula mengganggu stabilitas suatu negara.

Sedangkan pandangan FPI bahwa dakwah radikal yang mereka klaim sebagi hisbah telah ada di Indonesia sejak masuknya Islam di Indonesia perlu dikaji lebih mendalam. Karena berbagai literatur menyatakan bahwa Islam dapat masuk dan berkembang di Indonesia adalah dengan cara damai. Karena saat penduduk Indonesia sudah memiliki agama. Sedangkan terjadi berbagai peperangan oleh para tokoh agama pada masa penjajahan tidak bisa disamakan konteksnya dengan dakwah radikal dilakukan oleh FPI masa sekarang.

Pemahaman FPI tentang hisbah pada dasarnya sejalan dengan pengertian umum tentang hisbah sebagaimana dibahas di atas, bahwa hisbah adalah usaha untuk mencegah kemunkaran (pelanggaran) terhadap hak Allah dengan maksud menghindarkan orang yang dicegah dari melakukan kemunkaran. Namun jika ditelusuri lebih jauh, dalam konsep Islam, hisbah merupakan salah satu lembaga resmi pemerintahan. bisbah adalah lembaga pemerintahan yang berfungsi sebagai controler, monitor dan supervisor perkembangan kehidupan umat Islam, yang terkait aktivitas keagamaan, implemetasi prinsip-prinsip keadilan dan pelayanan umum. Dan jika dilihat dari sejarah hisbah sendiri sebagaimana telah dipraktikkan pada 
masa awal Islam dan telah dicontohkan di zaman Rasulullah Saw, tampaknya hisbah ini memainkan peran besar dalam mengawasi dan mengontrol sejumlah besar kegiatan ekonomi (khususnya di pasar), proyek-proyek sosial dan sipil (Taymiyyah, 1983: 142). Dengan kata lain, lembaga ini juga berperan sebagai lembaga pengawas pasar ekonomi yang memonitor perilaku para pelaku ekonomi agar berjalan sesuai dengan koridor dan mekanisme yang menjadi tujuan-tujuan syari'ah.

Jika memperhatikan penjelasan di atas, dapat dipahami bahwa para pejuang hisbah sebagaimana dilakukan kaum muslimin terdahulu yang dengan ketakwaannya dan kesungguhannya, melakukan yang ma'rüf dan mencegah yang munkar sangat diperlukan (Solikhin, 2005: 33) karena umat manusia yang sudah sangat tersesat memerlukan para mujtahid yang berkomitmen menegakkan hisbah, agar kehidupan ini tetap berlangsung. Namun, hisbah tersebut tidak bisa dilakukan dengan sekehendak sendiri dan dengan penafsiran sendiri pula, karena harus ada legitimasi dari penguasa setempat. Dengan demikian, penafsiran dan tindakan FPI yang mengatasnamakan hisbah dalam berbagai tindakan dan gerakannya yang kontroversial dan radikal tidak bisa dikatakan bisbah dalam konsep Islam sebagaimana telah dipraktikkan pada masa awal Islam, karena FPI bukan lembaga resmi yang ditugaskan pemerintah Indonesia untuk melakukan bisbah.

\section{PENUTUP}

Alquran menganjurkan pembentukan suatu kelompok atau segolongan umat yang intens berdakwah mengajak kepada kebaikan dan mencegah dari kemunkaran. Sedangkan hisbah memerintahkan kebaikan apabila ada yang meninggalkannya, dan melarang kemunkaran apabila ada yang melakukannya. Konsep hisbah merupakan doktrin Islam untuk memelihara segala sesuatu agar sesuai dengan syari'at Islam. Doktrin ini berdasar pada tuntunan Alquran dengan jalan memerintahkan kebaikan dan melarang kemunkaran. Secara teknis, hisbah juga merupakan salah satu lembaga resmi dalam pemerintah Islam yang berperan sebagai lembaga pengawas perilaku pelaku ekonomi agar sesuai dengan koridor syari'ah.

Dengan demikian, hisbah dan amar ma'rüf nahi munkar memiliki titik kesamaan. Namun amar ma'rüf nahi munkar merupakan kewajiban setiap individu sesuai kadar kemampuannya, sementara hisbah sekalipun memiliki arti sama dengan amar ma'rüf nahi munkar, namun dalam praktiknya harus mendapat legitimasi dari penguasa setempat.

Penelitian ini menyarankan perlu ada upaya dari tokoh-tokoh Islam, khususnya dari MUI, untuk menyadarkan FPI bahwa penafsiran dan berbagai tindakan radikal mereka yang mengatasnamakan hisbah perlu diluruskan, karena tidak sesuai dengan konsep hisbah sebagaimana telah dipraktikkan oleh kaum 
muslimin pada masa awal Islam. Hasil penelitian ini, diakui belum sempurna. Penulis berharap ada peneliti lainnya yang akan menggali dan menyempurnakan hasil penelitian ini, yang mengkaji secara khusus tentang konsep hisbah secara komprehensif kaitannya dengan amar ma'rüf nahi munkar yang dipraktikkan di beberapa negara Islam lain.

\section{DAFTAR PUSTAKA}

Abdullah, A. (2016). Gerakan Radikalisme dalam Islam: Perspektif Historis. Addin, Media Dialektika Ilmu Islam. 10(1) Februari 1-28

Abidin, Z. (2009), Buku Hitam Putih Dakwah Salafiah, Jakarta: Pustaka Imam Abu Hanifah.

Aditiya, E. (2013), Makna Radikalisme bagi Front Pembela Islam (FPI) Bandung Raya (Studi Fenomenologi Mengenai Makna Radikalisme bagi Front Pembela Islam Bandung Raya). Skripsi. Jurusan Ilmu Komunikasi, Fakultas Ilmu Sosial dan Ilmu Politik, Universitas Komputer Indonesia.

Al-Haritsi, J.A. (2003) Al-Fiqh al-Iqtishadi li Amiril Mukminin Umar Ibn alKhaththab, Terj. H. Asmuni Solihan Zamakhsyari Fikib Ekonomi Umar bin al-Khatab, Jakarta: Khalifa.

Al-Asimi, A. M. Q. (1984). Majmu' al-Fatawa Sayyid al-Islam Ibn al-Taimiyyah, Mesir: Dar al-Fikr.

Al-Mawardi, I. (1939) al-Ahkām al-Sultāniyah, Cet. Ke-3, Mesir: Syirkah wa Matba'ah Mustafa al-Babiy.

As-Sadr, S. M. (2003). Saling Memberi Saling Menerima, Jakarta: Zahra Publishing House.

Al-Zastrouw, Ng. (2006). Gerakan Islam Simbolik: Partai Kepentingan FPI. Yogyakarta: LKiS.

Amshari, F. (1995). Islam Kaffah: Tantangan Sosial Dan Aplikasinya Di Indonesia, Jakarta: Gema Insani Press.

Anwar, S. (2015). Pemikiran dan Gerakan Amr Ma'rûf Nahī Munkar Front Pembela Islam (FPI) di Indonesia 1989-2012. Teosofi 4(1): 220-250.

Asfar, M. (2003). Islam Lunak Islam Radikal. Surabaya: JP Press kerjasama dengan Pusat Studi Demokrasi dan HAM.

Basyir, K. (2014). Menimbang Kembali Konsep Dan Gerakan Fundamentalisme Islam Di Indonesia Al-Tabrir.; 14 (1): 23-45.

Burhani, A.N. (2001). Islam Dinamis Menggugat Peran Agama Membongkar Doktrin yang Membatu, Jakarta: PT. Kompas Media Nusantara.

Faiz, F. (2017). Front Pembela Islam: Antara Kekerasan dan Kematangan Beragama, Kalam; 8 (2): 347-366.

Fajar, A.M. (2005). Begawan Mubammadiyah: Bunga Rampai Pidato Pengukuhan Guru Besar Tokoh Muhammadiyah, Indonesia: PSAP. 
Ghafur, M. F. Demokrasi dan Fundamentalisme Agama: Kajian Teoritis. dalam Kartini, I. (2015). Demokrasi dan Fundamentalisme Agama: Hindu di India, Buddha di Sri Langka dan Islam di Turki Yogyakarta: Penerbit Andi

Hiarie, E (2010), Aksi dan Identitas Kolektif Gerakan Islam Radikal di Indonesia JSP: Jurnal Ilmu Sosial dan Ilmu Politik, 14 (2): 131-168.

Idrus, M. (2007). Metode Penelitian Ilmu-Ilmu Sosial, Yogyakarta: UII.

Islahi, A. A. (1996). Economic Concepts of Ibn Taimiyah, United Kingdom: The Islamic Foundation.

Jamhari, J. J. (2004). Gerakan Salafi Radikal di Indonesia, Jakarta:PT Raja Grafindo persada.

Kuntowijoyo, (2006). Islam Sebagai Ilmu : Epistimologi, Metodologi, dan Etika, Yogyakarta: Tiara Wacana.

Kuntowijoyo dan A. E. Priyono. (2008). Paradigma Islam: Interpretasi untuk Aksi, Bandung: Mizan.

Lewis, B. (1971). The Encyclopaedia of Islam, Vol. III, Leiden: E.J. Brill.

Ma'arif, S. (2012). Pemahaman Keberagamaan dan Gerakan Kelompok FPI Surabaya, Jurnal Theologia. 23 (2): 309-335.

Mahfūdh, S. A. dan Rauf, A. K. S. (1987). Hidāyat al-Murshidin; Dirāsat fì da'wah al-Islämiyyah. Kairo: Dār al-Tibā'ah al-Mahmadiyah.

Mahmūd, A. A. H, (1995). Dakwah Fardiyah: Membentuk Pribadi Muslim. Jakarta: Gema Insani.

Moleong, L. J. (1988). Metode Penelitian Kualitatif. Bandung: Rosdakarya.

Mujahidin, A. (2012). Peran Negara dalam hisbah. Al-Iqtishad. 4(1): 137-158.

Nasution, H. (1988). Teologi Islam: Aliran-aliran Sejarah, Analisa Perbandingan. Jakarta: UI Press.

Qomar, M. (2014). Implementasi Aswaja dalam Perspektif NU di Tengah Kehidupan Masyarakat, Kontemplasi. Volume 02 Nomor 01, Agustus. 161183.

Rahmat, M.I. (2005). Arus Baru Islam Radikal. Jakarta: Erlangga.

Ro'uf, A. M. (2007), Mengurai Radikalisme Agama di Indonesia Pasca Orde Baru, Ulumuna, 11(1). 157-176.

Rosadi, A. (2003). Hitam dan Putih FPI. Jakarta: Nur Publisher.

Saifuddin, (2011). Radikalisme Islam di Kalangan Mahasiswa (Sebuah Metamorfosa Baru). Skripsi. Universitas Islam Negeri Sunan Kalijaga Yogyakarta.

Shihab, A. dan Nurul A. Rustamaji. (1999). Islam Inklusif Menuju Sikap Terbuka dalam Beragama. Bandung: Mizan.

Shihab, H. M. R. (2008). Dialog FPI-Amar Ma'rūf Nahī Munkar. Jakarta: Ibnu Saidah.

Solikhin, I. (2005). Wilayah hisbah dalam Tinjauan Historis Pemerintahan Islam, Ibda'Jurnal Studi Islam dan Budaya. 3(1): 33-44 
Sukamto. (2016). Kontektualisasi Institusi hisbah dalam Perekonomian Indonesia Praspektif Maqashid Syariah, Malia, Volume 7, Nomor 1, Februari: 59-80 Sukayat, T. (2012). Revitalisasi Ilmu Dakwah: Kajian Mabadi 'Asrab Ilmu Dakwah. Ilmu Dakwab: Academic Journal for Homiletic Studies. 6(2) Desember: 195-206

Taymiyyah, I. (1396). al-Amr bi al-Ma'rüf wa al-Nabī 'an al-Munkar, Cet. Ke-1, Beirut: Dār al-Kitāb al-Jadīd.

Taymiyyah. I. (1983). al-Hisbah fi al-Islâm, Kuwait: Maktabat Dâr al-Arqâm.

Thalib, J. U. (2003). "Radikalisme dan Islamo Phobia", dalam Z.A. Maulani dkk., (ed.) Islam dan Terorisme. Yogyakarta: UCY, 2003.

Thalkhah, I. (2005). (editor), Gerakan keislaman pasca Orde Baru: upaya merambah dimensi baru Islam, Jakarta: Badan Litbang Agama.

Thalkhah, I. dan Fuad C. (2002). Gerakan Islam Kontemporer di Era Reformasi. Jakarta: Badan Litbang Agama dan Diklat Keagamaan Depag RI.

Tim Litbang Kompas. (1999). Parta-Partai Politik. Indonesia: Ideologi, Strategi, dan Program, Jakarta: Kompas.

Tim Penyusun, (1994). Ensiklopedi Nasional Indonesia. Jilid 14, Jakarta: Cipta Adi Pustaka.

Turmudi, E. Dkk. (2004). Islam dan Radikalisme di Indonesia, Jakarta: LIPI Press, 2004.

Yunus, M. (1989). Kamus Arab-Indonesia. Jakarta: PT. Hidakarya Agung.

Zada, K. (2002). Islam Radikal: Pergulatan Ormas-Ormas Islam Garis Keras di Indonesia, Jakarta: Teraju, 2002. 